\title{
Firm Characteristics and the Extent of Voluntary Disclosure: The Case of Egypt
}

\author{
Mohamed Moustafa Soliman \\ Arab Academy for Sciences \&Technology, College of Management \&Technology, Alexandria- Egypt \\ E-Mail:Mohamed.soliman@aast.edu
}

\begin{abstract}
In a society depending on real time information, corporate disclosure is crucial for the capital market efficiency. The more disclosures a company makes, the more transparent becomes the information to investors, the lower becomes the information asymmetry and more credible the firms will be for the market. The purpose of this study is to investigate the association between the voluntary disclosure level in annual reports and firm characteristics of more active 50 Egyptian companies listed on the Egyptian Stock Exchange of the non-financial sector during the period 2007-2010. The firm characteristics used in the study are: firm size, auditor size, profitability, and firm's age. A disclosure checklist consisting of 60 voluntary items of information is developed and statistical analysis is performed using multiple regression analysis. The results of univariate and multivariate analyses indicated that firm size and profitability have significant positive association with voluntary disclosure level in annual reports. On the other hand, auditor size and firm's age do not have any significant association with voluntary disclosure level. However, this paper has contributed to the academic literature that firms in the Middle East provide voluntary corporate information which builds a confidence to the investors in general.
\end{abstract}

Keywords: Firm Characteristics; Annual reports; Voluntary Disclosure; Egypt

\section{Introduction}

Voluntary disclosure in the annual reports and in other information media has been one of the rapidly growing research areas in the accounting field. In this, several factors have played important roles. Among them are development of communication tools, stakeholders' need for more transparency, accountability, and corporate governance practices (Bleck and Liu, 2007). Earlier studies have evaluated the extent of voluntary disclosure made by corporations in many developed countries, and provided evidences of firm characteristics which have impact on voluntary disclosure level.

Emerging capital markets break from those of developed countries in that they have high-growth potential, relatively weak regulatory environment, weak corporate governance leading to expropriation of minority shareholders, and low information disclosure level causing high information gap between managers and investors. Thus, research studies about these markets are needed and are vital in improving the weak transparency and disclosure situation by attracting the attention of regulatory bodies and firm managers (Alsaeed, 2006).

The subject of information disclosure is not only limited to the exclusive users but also consists of people's necessity in the society such as professional institutions, creditors, government, investors and other decisionmakers. Disclosure increase transparency while market transparency is observed as a fundamental mechanism in order to decrease the information asymmetry among the market's participants (Bleck and Liu, 2007). Disclosure helps the stockholders and other participants in market to organize their operations favorably. The investors can buy and sell stocks accurately and have control over the company with the help of proper disclosure of information (Kohl and Schaefers, 2012).

Proper disclosure is based on the ethics that all potential users be considered the same with regard to the financial information disclosure. Complete disclosure indicating the present of all information in a way that financial statement show complete picture concerning events and transactions of business enterprise. Although, it is necessary to be presented financial statement completely but, it is not included unimportant information. Because, users of financial statements may pay attention to less important information and as a result of this, neglect important events and operations (Alivar, 2006 ).

Transparency generates benefits for the global economy. Foreign direct investment increases with the corporate transparency (Rees and Weisbach, 2002). Based on the assumptions of the behavioural finance, Bremer and Elias (2007) argue that the main cause of home bias is the inability of many foreign firms to attract the initial attention of investors, concluding that investors tend to spend their money in a larger amount of domestic equities, despite the payback of foreign equities. The inability to attract foreign investors could be eliminated with more efforts to improve financial reporting practices (Al-Shammari, 2008).

In this study, an important aspect is the definition of "voluntary disclosure". Consistently with prior definitions in different regulatory national environments (Raffournier, 1995; Meek et al., 1995; Depoers, 2000; and Larmou and Vafeas, 2010). This study considers voluntary disclosure as the information released to the outside deriving 
from management's insider knowledge of the company, which are not required to be published in regulated reports. Voluntary disclosure is, therefore, produced by a management's reporting decision (Meek et al., 1995; and Healy and Palepu, 2001).

Disclosure in the management annual report is a form of disclosure which is not yet strictly regulated in Egypt, the thing which makes the research, in this area, necessary. Actually, what is nowadays disclosed on a voluntary basis is likely to be included in the foundations of standardization and the future regulations. This could be achieved as a response to the needs of the Egyptian external users of the annual reports since their need for information is constantly growing.

An important practical motivation for this study is the better understanding of the voluntary disclosure practices in a non-Anglo- American country that has not been extensively examined. The relevance of this paper is based on several reasons. First, it contributes to the recent literature on the information transparency and accountability. Second, it can be of interest to both managers and investors, because of the influence of transparency on domestic and foreign investments. Finally, the study addresses voluntary disclosure practices over the period of considerable changes in the business environment in general and the capital market in particular. The period of the study has witnessed, among other changes, the first application of the new listing rules and the issuance of an Egyptian corporate governance code. Also, the results of the analysis are expected to help explain the variation of current and prospective voluntary disclosure extent in light of the aforementioned firm characteristics.

The paper proceeds as follows. The next section provides a literature review and development of hypothesis. Section three describes the methodology, and the data. Section four reports the empirical results and the robustness checks. Finally, section five concludes the paper.

\section{Literature Review and Development of Hypothesis}

Emerging markets have become the focus of international corporations, personal and institutional investors due to their high rates of economic growth (Millar et al., 2005). However, they suffer from low investor protection practices, especially expropriation of minority shareholders both by managers and controlling shareholders (Gonenc and Aybar, 2006). They have higher information asymmetry between managers and investors (Gul and Leung, 2004; Chau and Gray, 2010), and have lower level of disclosure than those in developed market economies (Salter, 1998; Tower et al., 2011; And Wang et al., 2008). These two factors (i.e. low minority investor protection and low disclosure level) might be detrimental by keeping foreign investors away from the marketplace, and set an obstacle to the international capital flow toward these economies. Mitton (2002) states that disclosure quality and legal protection of minority shareholders are two key elements of corporate governance. Thus, firms have to respond positively to increasing demand for higher transparency and disclosure by investors in face of severe competition for international capital (Kohl and Schaefers, 2012). Young and Guenther (2003) found that disclosure of value-relevant accounting information has a positive effect on international capital mobility; therefore, they state that reducing information barriers may improve international capital mobility.

Voluntary disclosure refers to additional information delivered by firms beside the mandatory information. To reduce the information asymmetry between a leader and an investor, we must have the case where the former discloses voluntary information to the latter. This is essentially going to contribute to the alleviation of problems of adverse selection and of moral risk. Voluntary disclosure is regarded as an external mechanism for the control of the leaders, a protection of the shareholders, and a decrease of the agency costs resulting from the asymmetry of information between the insiders and the outsiders (Wang et al., 2008). Giving this crucial role of voluntary corporate reporting policy, a considerable research area has been developed in order to identify factors that have the potential of affecting corporate voluntary disclosure practices in both emerging and developed markets. Although many factors have been identifies, the empirical evidence is rather mixed.

Aljifri (2008) examined the extent of disclosure in annual reports of 31 listed firms in the UAE and also determined the underlying factors that affect the level of disclosures. The study hypothesized that four main factors would affect the extent of disclosure in the UAE, namely, the sector type (banks, insurance, industrial, and service), size (assets), debt-equity ratio, and profitability. Findings indicated that significant differences were found among sectors; however, the size, the debt-equity ratio, and the profitability were found to have insignificant association with the level of disclosure.

Alsaeed (2006) studied the association between firm-specific characteristics and disclosure in Saudi Arabia. A total of 20 voluntary items developed to assess the level of disclosure in the annual reports of 40 firms. The results showed that the mean of the disclosure index was lower than average. It was also found that firm size was significantly positively associated with the level of disclosure however, debt, ownership dispersion, age, profit margin, industry and audit firm size were found to be insignificant in explaining the variation of voluntary disclosure. 
In Egypt, Dahawy (2009) investigated the relationship between company characteristics and disclosure level. The study is based on the manual examination of the disclosure of the most activity traded 41 companies listed on the Cairo and Alexandria Stock Exchange (CASE), using a disclosure checklist issued by the Egyptian Capital Market Authority (CMA). A quantitative analysis is then used to test the relationship between corporate characteristics and disclosure level. The findings of research indicate that the degree of disclosure by Egyptian companies is affected by the highly secretive Egyptian culture. The results further indicate that the degree of affiliation of the auditor with an international firm is the most significant variable affecting the level of disclosure by Egyptian companies and are then compared to their counterparts in previous studies.

\section{2-1. Firm Size and Voluntary Disclosure}

The firm size is considered as one of the most important variables related with the level of transparency (Lang and Lundholm, 2000). Large companies face greater agency costs because they require large volumes of external capital to finance their investments (Jensen and Meckling ,1976). Marston and Polei (2004) claim that higher level of disclosure is expected to decrease agency cost which may arise from the conflicting interests of shareholders, managers and debt holders. Watts and Zimmerman (1990) also argue that the political costs are greater in large organizations. Consequently, large firms tend to disclose more information to reinforce confidence and to reduce such costs. Furthermore, voluntary disclosures are expected to decrease political costs that are higher for larger companies compared to smaller companies (Marston and Polei, 2004).

Literatures find evidence that larger firms disclose more information (e.g. Meek et al., 1995; Hossain et al., 1995; Camfferman and Cooke, 2002; Eng and Mak, 2003; and Wang et al., 2008). Also Beattie et al., (2004) find a positive relation between the size and the reporting of British companies. Hence, the following hypothesis is stated:

\section{H1: There is a positive association between firm size and the voluntary disclosure in annual reports. 2-2. Auditor Size and Voluntary Disclosure}

The audits indicator is a measure of the reliability of financial accounting disclosures (Bushman et al., 2004). Earlier studies have investigated the association between auditor size and the disclosure level of corporations (Wang et al., 2008; Wallace et al., 1994; and Bonsón and Escobar, 2006). Malone et al., (1993) argue that smaller auditing firms are more sensitive to client demands because of the economic consequences associated with the loss of a client; on the other hand, larger firms have a greater incentive to demand adverse disclosures from the client. A number of studies failed to discover a significant relationship between the auditor size and disclosure level (Wallace et al., 1994; Hossain et al., 1995; Malone et al., 1993). On the other hand, many earlier studies have found a positive association between the auditor size and the extent of disclosure (Patton and Zelenka, 1997; Raffournier, 1995; and Bonsón and Escobar, 2006). Hence, the following hypothesis is stated:

H2: There is a positive significant association between auditor size and the voluntary disclosure in annual reports.

\section{2-3. Profitability and Voluntary Disclosure}

There is a general proposition that a company's willingness to disclose information is positively related to its profitability. One motive for this can be derived from agency theory. It is suggested that managers of profitable companies disclose extensive information in order to show and explain to shareholders that they are acting in their best interests and justify their compensation packages. Similarly, management of a profitable company wishes to disclose more information to the public to promote positive impression of its performance (Ghazali and Weetman, 2006).

The association between profitability and voluntary disclosure has also been investigated in previous studies (Wang et al., 2008; and Marston and Polei, 2004). Ghazali and Weetman (2006) argue that the more profitable the companies, the more likely it is for them to disclose financial information. Marston and Polei (2004) also stress that "good news" firms are encouraged to distinguish themselves out from other firms by disclosing more information. This provides the basis for the following hypothesis:

\section{H3: There is a positive association between profitability and the voluntary disclosure in annual reports.}

\section{2-4. Firm's Age and Voluntary Disclosure}

Camfferman and Cooke (2002) identified a number of new variables, such as the age of the company to be investigated by future studies. The rationale for selecting this variable lies in the possibility that old firms might have improved their financial reporting practices over time (Alsaeed, 2006) and secondly they try to enhance their reputation and image in the market (Akhtaruddin, 2005). Owusu and Yeoh (2005) state three points in this case. First, younger companies may suffer competitive disadvantage if they disclose certain items such as information on research expenditure, capital expenditure, and product development. The second factor is the cost and the ease of gathering, processing, and disseminating the required information. These costs are likely to be more onerous for younger companies than for their older counterparts. The third and final factor is the situation that younger companies may lack a 'track record' to rely on for public disclosure and therefore may have less information to disclose or less rich disclosures. Therefore, in principle the age of the firm can be offered as an 
independent variable in explaining disclosure level. However, on the balance of the theory and evidence, this study presents the following hypothesis:

\section{H4: There is a positive association between firm's age and the voluntary disclosure in annual reports.}

\subsection{Voluntary Disclosure Evolution in Egypt}

Researchers have, historically, found Egypt's business society to be highly secretive (Dahawy et al, 2002). Samaha and Dahawy (2011) argued that Egypt's case presents a classical confrontation between a historically secretive society and the requirement for high disclosure levels to attract direct foreign investments. However, the Egyptian government, business world and media have consistently reported the need for direct foreign investment and hence the increase in disclosure levels. This has resulted in increased significance of the Egyptian Stock Exchange (previously the Cairo and Alexandria Stock Exchange (CASE) as an important venue for attracting foreign investments and to encourage local residents to invest in shares. A critical factor for achieving this objective is the transparency and fairness of corporate disclosures. Therefore, Egyptian firms may engage in voluntary disclosure to enhance the value of their stocks. The voluntary use of the Internet in corporate communications should help Egyptian firms to meet stakeholders' needs for information, and thereby promote the confidence of national and foreign investors (Samaha and Abdallah, 2011).

In Egypt, international accounting firms can only operate through an Egyptian partner. In addition, the audit profession and auditor independence have been well regulated since the 1950s. The argument that large audit firms are more independent, stricter with their clients and more sensitive to their reputation than small audit firms, can apply to large local and international firms (Abd-Elsalam and Weetman, 2003).

In Egypt, we are witnessing in these recent decades, some changes characterizing in the economic environment. Several working groups were created to reflect upon the mechanisms to be set up in order to promote good corporate governance beyond the legal obligations of disclosure.

\section{Research design \\ 3.1. Sample}

The sample in the current study consists of the Egyptian companies from amongst the top 50 most active-traded companies listed in the Egyptian Stock Exchange over the period 2007-2010. Following the majority of disclosure literature (e.g. Wallace and Naser, 1995; Haniffa and Cooke, 2002; and Ghazali and Weetman, 2006) financial companies; e.g. banks, insurance companies, and leasing companies; were excluded from the sample due to the different requirements of disclosure and corporate governance. Hence their annual reports may be not comparable to those of other companies. This gave us a sample of 40 firms. As no relevant Data Stream exists in Egypt, the annual reports, covering the four year period 2007-2010, were purchased from the Egyptian Company for Information Dissemination (EGID) to extract the information on the variables needed to test each of the research hypotheses.

\subsection{Construction of the disclosure Index}

The voluntary disclosure index (VDISCL) is based on the information firms provide in their annual reports to shareholders. The index is similar to that in Eng and Mak (2003); Peterson and Plenborg (2006); and Alivar (2006). Common to these studies is that they focus on investors' needs. The disclosure index is based on the following six categories: strategy, market and competition, management and production, marketing, future perspective and human capital. A score sheet was designed for scoring firms on the amount and the level of detail of disclosures. A total of 60 indicators within the six groups have been identified (See appendix A). The disclosure index is un-weighted as it assumes that each indicator of each disclosure category is equally important (Gray et al., 1995). The disclosure level of a company was calculated by dichotomous procedure which assigns a score of 1 if a corporation discloses an item and a score of 0 if it does not (Cooke, 1989; Gul and Leung, 2004; and Hossain and Hammami, 2009). For each firm, a disclosure index was computed as the ratio of the actual score given to the firm divided by the maximum score. Accordingly, the voluntary disclosure index for each company was calculated as follows (Cooke, 1989; Hossain and Reaz, 2007; and Hossain and Hammami, 2009):

$$
\text { VDISCL }=\sum_{\mathrm{n}=1}^{\mathrm{dj} / \mathrm{n}}
$$

Where: VDISCL is voluntary Disclosure index level, $\mathrm{dj}=1$ if the item $\mathrm{j}$ is disclosed; 0 if the item $\mathrm{j}$ is not disclosed; $n$ is number of items.

This study proceed to the validation of the voluntary disclosure index, following Botosan (1997), based on the following points: comparison with similar studies using voluntary disclosure indexes; positive statistically significant correlations between the number of analysts and the voluntary disclosure scores; an accepted value for the Cronbach's alpha coefficient; and similar results with previous studies of the correlation between the voluntary disclosure level and firm characteristics.

\subsection{Definition of Variables}

The explanations of dependent and independent variables are presented in Table 1. Most measurements and expected relations are consistent with prior research (Cooke, 1989; Gul and Leung, 2004; and Hossain and 
Hammami, 2009).

There are a number of companies that were in the top 50 most active-traded companies listed in the Egyptian Stock Exchange in 2007 that are not in 2010 raising concerns regarding the effect that non-surviving firms have on the results. To control the effect of non-survivorship firms on the results, a dumpy variable (FSUR) is created which is equal to 1 if the firm is continuously present in all the years of the sampling period from 2007 to 2010 , otherwise it is equal to 0 .

Table 1: Dependent and Independent Variables

\begin{tabular}{|c|c|c|c|}
\hline Variable & Indicators & Explanation & $\begin{array}{l}\text { Expected } \\
\text { signs }\end{array}$ \\
\hline $\begin{array}{l}\text { Dependent } \\
\text { Variable } \\
\text { Voluntary } \\
\text { Disclosure index } \\
\text { level }\end{array}$ & VDISCL & $\begin{array}{l}\text { Which assigns a score of } 1 \text { if a firm discloses an item and a } \\
\text { score of } 0 \text { if it does not. For each firm, a disclosure index was } \\
\text { computed as the ratio of the actual score given to the firm } \\
\text { divided by the maximum score. }\end{array}$ & \\
\hline $\begin{array}{l}\text { Independent } \\
\text { Variables } \\
\text { Firm Size }\end{array}$ & FSIZE & Which is measured by Log of the book value of total assets & + \\
\hline Auditor Size & AUDSIZE & $\begin{array}{l}\text { Type of the auditor (that is, } 1 \text { if auditor is a member of Big- } 4 \\
\text { auditing firms, } 0 \text { if auditor is not a member of Big- } 4 \text { auditing } \\
\text { firms). }\end{array}$ & + \\
\hline Profitability & PROFT & $\begin{array}{l}\text { This is measured by return on assets (that is, net income/total } \\
\text { assets). }\end{array}$ & + \\
\hline Firm's Age & FAGE & This is measured by Log of the age of firm. & + \\
\hline
\end{tabular}

\subsection{Model development}

The model employed to test the relationship between the voluntary disclosure level and firm characteristics is presented below:

$$
\text { VDISCL }=\beta 0+\beta 1 F S I Z E+\beta 2 A U D S I Z E+\beta 3 P R O F I T+\beta 4 F A G E+\beta 5 F S U R+\varepsilon
$$

Where: VDISCL, voluntary disclosure index level; FSIZE, firm size; AUDSIZE, auditor size; PROFIT, profitability; $\boldsymbol{F A G E}$, firm's age; $\boldsymbol{F S U R}$, firm survival; and $\boldsymbol{\varepsilon}$, the error term, normally distributed about a mean of 0 .

\section{Results discussion \\ 4.1 Descriptive statistics}

Table 2 provides the minimum, maximum, mean, and standard deviation of the variables in the study. The table indicates that the level of average voluntary disclosure in the sample companies is $32 \%$ with a minimum of $21 \%$ and a maximum of 65\%. It is consistent with Leventis and Weetman (2004) in Greece (37\%); Al-Shammari (2008) in Kuwait (46\%); Ghazali and Weetman (2006) in Malaysia (31\%); and Hossain and Hammami (2009) in Qatar $(37 \%)$. The low amount of voluntary information disclosed in the body of financial reports could be explained on the basis that this type of information is voluntary in nature, and no effective regulations enforce firms to reveal it. The results also, reveal that (31\%) of companies sampled are audited by the big 4 audit firms. Profitability has -21.88 and 78.20 as minimum and maximum value respectively, mean value 16.65 and standard deviation 10.6343. Last independent variable, age of firm has 5 and 46 as minimum and maximum value respectively, mean value 16.45 and standard deviation 13.8721 .

Table 2. Descriptive statistics for study variables

\begin{tabular}{|l|c|c|c|c|c|}
\hline \multicolumn{1}{|c|}{ Variable } & Label & Min & Max & Mean & Std. Deviation \\
\hline Voluntary Disclosure Level & VDISCL & 21.11 & 64.86 & 31.92 & 13.6684 \\
Firm Size & FSIZE & 9.96 & 17.82 & 13.92 & 2.6087 \\
Auditor Size & AUDSIZE & 0 & 1 & .310 & .46790 \\
Profitability & PROFIT & 21.88 & 78.20 & 16.65 & 10.6343 \\
Firm's Age & FAGE & 4 & 46 & 16.45 & 13.8721 \\
Firm Survival & FSUR & 0.00 & 1 & .3095 & .44865 \\
\hline
\end{tabular}

\subsection{Correlation matrix and multicollinearity analysis}

Multicollinearity in explanatory variables has been diagnosed through analyses of correlation factors and Variable Inflation Factors (VIF), consistent with Weisberg (1985); Al-Shammari (20080; and Hossain and Hammami (2009). Table 3 presents the correlation matrix of the dependent and independents variables, from which, it has been observed that the highest simple correlation between independent variables was 0.655 between auditor size (AUDSIZE) and firm's age (FAGE). Bryman and Cramer (1997) suggest that simple 
correlation between independent variables should not be considered harmful until they exceed 0.80 or 0.90 . This confirms that there is no multicollinearity among the variables. The further confirmation of mutlitolinearity assumption is checked by variance inflation factor (VIF). The (VIF) in excess of 10 should be considered an indication of harmful multicollinearity (Neter et al., 1989). Alternatively, if the average VIF is substantially greater than 1 then the regression may be biased (Bowerman and O'Connell, 1990). Table 4 shows that the average VIF (1.47) is close to 1 and this confirms that collinearity is not a problem for this model. These findings suggest that multicollinearity between the independent variables is unlikely to pose a serious problem in the interpretation of the results of the multivariate analysis.

Table 3. Correlation coefficients Matrix of the variables used in the study:

\begin{tabular}{|c|c|c|c|c|c|c|}
\hline Variable & VDISCL & FSIZE & AUDSIZE & PROFIT & FAGE & FSUR \\
\hline VDISCL & $\mathbf{1}$ & & & & & \\
\hline FSIZE & .584 & 1 & & & & \\
\hline AUDSIZE & .340 & .137 & 1 & & & \\
\hline PROFIT & .224 & .342 & .224 & 1 & & \\
\hline FAGE & .207 & .136 & .655 & -.640 & 1 & \\
\hline FSUR & .476 & .223 & -.424 & .173 & .374 & 1 \\
\hline
\end{tabular}

\subsection{Multivariate analysis}

As in many previous disclosure studies, regression analysis has been preferred to investigate the association between firm characteristics and voluntary disclosure level of Egyptian companies. Results of an Ordinary Least Square (OLS) regression in Table 4 show that the F-ratio is $12.84(\mathrm{P}=0.00)$. The result statistically supports the significance of the model. The value obtained for the adjusted coefficient of determination $\mathrm{R}$ square of the model was .6198. This tells us how much of the variance in the dependent variable (total voluntary disclosure index) is explained by the model. Given these results, the study concludes that the variables considered in the model largely explain the voluntary disclosure of companies.

\subsection{Results of Regression Model}

Table 4 provides the results of the OLS regression for the model using the stepwise method. Firm characteristics including firm size; profitability; and age of firm have positive and significant relationship with voluntary disclosure index. While auditor size has positive but insignificant relationship with voluntary disclosure index. Unless otherwise noted, the following discussion refers to the normal scores-regression results which are in complete agreement from the rank regression results.

The hypothesis $\mathbf{H 1}$ predicted a significant and positive relation between companies' size and voluntary disclosure. The study result supports this hypothesis. The firm size has been found to be significantly and positively correlated with disclosure level. In a number of studies, suggesting that larger companies disclose more information, either mandatory or voluntary, than smaller companies (Cooke, 1989; Meek et al., 1995; Hossain et al., 1995; Camfferman and Cooke, 2002; Eng and Mak, 2003; and Wang et al., 2008). The argument rely on the fact large firms tend to have more voluntary disclosure because they need more financing capital than smaller firms. Furthermore, large firms are closely watched by investors and have the ability to absorb extra costs for broader disclosure. This positive statistical significant result between the firm size and the voluntary disclosure can be also explained by the fact that larger firms make a more extensive use of the capital markets and have a greater number of analysts following them (Lang and Lundholm, 2000). These facts make the companies willing to provide more information to the market. Furthermore, this result also shows that companies are worried about their legitimacy. Companies that feel more observed tend to increase the level of disclosure to keep their reputation and ensure their survival (Alivar, 2006).

Table 4. Regression results

\begin{tabular}{|c|c|c|c|c|}
\hline \multicolumn{5}{|c|}{$V D I S C L=\beta 0+\beta 1 F S I Z E+\beta 2$ AUDSIZE $+\beta 3$ PROFIT $+\beta 4 F A G E+\beta 5 F S U R+\varepsilon$} \\
\hline Variable & $\beta$ & t-value & Sig. & $V I F$ \\
\hline Constant & -8.287 & -3.936 & .000 & \\
\hline FSIZE & 2.157 & 3.697 & .037 & 1.38 \\
\hline AUDSIZE & .046 & .726 & .376 & 1.42 \\
\hline PROFIT & .358 & .892 & .024 & 1.23 \\
\hline FAGE & .318 & 2.953 & .065 & 1.49 \\
\hline FSUR & -1.962 & -5.154 & 0.127 & 1.87 \\
\hline \multicolumn{5}{|c|}{ Model Summary } \\
\hline $\boldsymbol{R}$ & & & & .7873 \\
\hline R square & & & & .6198 \\
\hline Adjusted R sq & & & & .5842 \\
\hline F-value & & & & 12.84 \\
\hline Sig. & & & & 0.00 \\
\hline
\end{tabular}


Where: VDISCL, voluntary disclosure index level; FSIZE, firm size; AUDSIZE, auditor size; PROFIT,

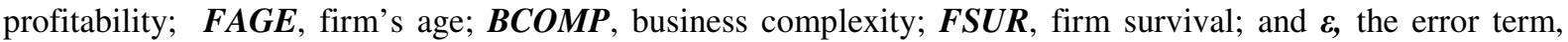
normally distributed about a mean of 0 .

The empirical evidence derived from the regression model results in Table 3 and 4 indicate that audit firm size is statistically related to the level of voluntary disclosure by the sample of companies in their annual reports. But it is non-significant at $.05 \%$ level. This finding lends nonsupport to Hypothesis 2 . The rationale justification behind this result lies in the possibility that the role of auditors is limited to the boundaries of mandatory information. Simply put, auditors, in general, do not require their clients to report data in excess of that required by the accounting standards. The non-significance of auditor type in explaining variation in corporate disclosure is consistent with the vast majority of prior studies in both developed capital markets (for example, Malone et al., 1993, Wallace et al., 1994; and Camfferman and Cooke, 2002) and emerging capital markets (for example, Chen and Jaggi, 2000; Haniffa and Cooke, 2002; Gul and Leung, 2004; Barako et al., 2006; and Hossain and Hammami, 2009).

The hypothesis $\mathbf{H 3}$ predicted a positive relation between companies' profitability and voluntary disclosure. This study result supports the previous hypothesis. This result suggests that companies that are performing well tend to voluntarily disclose more information. The positive statistical significant relation between organizational profitability and the voluntary disclosure index also corroborate the argument of Meek et al., (1995) and of Hossain and Hammami (2009). Also according to Wang et al., (2008) as the firm's earnings increase, managers have incentives to supply more information to the market in order to signal quality. On the other hand, voluntary disclosure helps investors to differentiate the high quality stocks. Furthermore, this result cans also analyse in light of the legitimacy theory. In this sense, companies with good performance feel persuaded by the social contract to perform voluntary reporting of their activities and results. According to the signaling theory, it was expected that managers of companies that are performing well disclose more information about their present situation, in order to send signs to the market about the quality of the companies they manage (Alivar, 2006).

The results in Table 3 and 4 don't find a statistical significant association between firm's age and the voluntary disclosure index, but the coefficients are positive. This finding lends nonsupport to Hypothesis 4 . This can be explained by the signaling objectives and the legitimacy of the newly listed companies and is consistent with that found by Bushee et al., (2003); and Akhtaruddin (2005).

\section{Conclusion}

This paper reports on the level of voluntary disclosure of a sample of non-financial Egyptian firms listed on the Egyptian Stock Exchange over the period 2007-2010 and, then investigates the association between the level of disclosure and firm-specific characteristics. Unweight disclosure index, compiled of 60 voluntary items, was computed for each firm. The study found that firms, on average, report 0.32 percent of the voluntary information. The low disclosure level most likely relates to the fact that this type of information is voluntary in nature, and no existing disciplines set out by the authoritative accounting and reporting bodies in Egypt require public firms to display such information. In other words, voluntary disclosure is left to the discretion of management. Further, in an effort to examine the relationship between the voluntary disclosure level and firmspecific characteristics, the results of univariate and multivariate analyses indicated that firm size and profitability have significant positive association with voluntary disclosure level in annual reports. On the other hand, auditor size and firm's age do not have any significant association with voluntary disclosure level.

This study recommends to management and auditors of Egyptian companies to improve the quality and reporting of voluntary disclosure in their annual reports. This will enhance the confidence of their investors, satisfying their creditors and customers, improve their profitability and value of shares. Also, regulatory bodies in Egypt have got some implications; they are expected to guide firms toward the best practices of voluntary disclosures since firms look for such guidance. They play a motivating role in this new era of information disclosure.

As with any research, this study has some limitations. The following limitations are the most pertinent. First, the items constituting the disclosure index were subjectively assembled from three prior studies. The choice of the items, however, does not reflect their level of importance as perceived by financial information users. Second, annual reports have been used as the sole source of data gathering, others such as web sites and press releases could be used in future studies. Finally, the findings may not be valid for non-listed companies.

\section{References}

Abd-Elsalam, O. \& Weetman, P. (2003), "Introducing International Accounting Standards to an Emerging Capital Market: Relative Familiarity and Language Effect in Egypt”, Journal of International Accounting, Auditing and Taxation 12(1), 63-84.

Akhtaruddin, M. (2005), "Corporate mandatory disclosure practices in Bangladesh", International Journal of Accounting 40, 399-422. 
Alivar, A. (2006), "Disclosure in financial reporting", Center for Professional Accounting \& Auditing Studies: Audit Organization.

Aljifri, K. (2008) "Annual report disclosure in a developing country: The case of the UEA", Advances in Accounting 24, 93-100.

Alsaeed, K. (2006), "The association between firm-specific characteristics and disclosure: the case of Saudi Arabia", Managerial Auditing Journal 21(5), 476-496.

Al-Shammari, B. (2008), "Voluntary disclosure in Kuwait corporate annual reports", Review of Business Research 1, 10-30.

Barako, D., Hancock, P., \& Izan, H. (2006), "Factors Influencing Voluntary Corporate Disclosure by Kenyan Companies", Corporate Governance 14(2), 107- 125.

Beattie, V., McInnes, B., \& Fearnley, S. (2004), "A Methodology for analysing and evaluating narratives in annual reports: a comprehensive descriptive profile and metrics for disclosure quality attributes", Accounting Forum 28, 205-236.

Bleck, A., \& Liu, X. (2007). "Market transparency and the accounting regime", Journal of Accounting Research 45(2), 229-256.

Bonson, E.; and Escobar, T. (2006), "Digital reporting in Eastern Europe: An Empirical study", International Journal of Accounting Systems 7, 299-318.

Botosan, C. (1997), "Disclosure level and the cost of equity capital", The Accounting Review 72, 323-349.

Bowerman, B. L., \& O'Connell, R. T. (1990). Linear statistical models: An applied approach, 2nd ed. Belmont, CA: Duxbury.

Bremer, J., \& Elias, N. (2007), "Corporate Governance in Developing Economies- the Case of Egypt, International Journal of Business Governance and Ethics 3(4), 430-454.

Bryman, A., \& Cramer, D. (1997). Quantitative data analysis with SPSS for windows. London: Routledge.

Bushee, B.J. Matsumoto, D.A. \& Miller, G.S. (2003), "Open versus closed conference calls: the determinants and effects of broadening access to disclosure", Journal of Accounting and Economics 34, 149-180.

Bushman, R.; Piotroski.L; \& Smith, A. (2004), "What Determines Corporate Transparency?", Journal of Accounting Research 42(2), 207-252.

Camfferman, K., \& Cooke, T. (2002), "An analysis of Disclosure in the Annual Reports of UK and Dutch Companies", Journal of International Accounting Research 1, 3-30.

Chau, G. \& Gray, J. (2010), "Family ownership, board independence and voluntary disclosure: evidence from Hong Kong", Journal of International Accounting, Auditing and Taxation 19 (2), 93-109.

Chen, C., \& Jaggi, B. (2000), “Association between Independent Non-Executive Directors, Family Control and Financial Disclosures in Hong Kong”, Journal of Accounting and Public Policy 19: 285-310.

Cooke, T. (1989), "Voluntary Corporate Disclosure by Swedish Companies", Accounting and Business Research 19 (74), 113-124

Dahawy, K. (2009), "Company characteristics and disclosure level: The case of Egypt", International Research Journal of Finance and Economics 34, 194-208.

Dahawy, K., Merino, B.D., \& Conover, T.L. (2002). "The conflict between IAS disclosure requirements and the secretive culture in Egypt", Advances in International Accounting 15, 203-228.

Depoers, F. (2000), "A cost benefit study of voluntary disclosure: some empirical evidence from French listed companies", European Accounting Review 9, 245-263.

Eng, L., \& Mak, Y. (2003), "Corporate Governance and voluntary disclosure", Journal of Accounting and Public Policy 22, 325-345.

Ghazali, N., \& Weetman, P. (2006), "Perpetuating traditional influences: Voluntary disclosure in Malaysia following the economic crisis", Journal of International Accounting, Auditing and Taxation 15(2), 226-248.

Gonenc, H. \& Aybar, C. (2006), "Financial crisis and firm performance: empirical evidence from Turkey, Corporate Governance: An International Review 14 (4), 297-311.

Gray, R.; Owen, D.; \& Adams, C. (1995). “Accounting and Accountability: Changes and Challenges in Corporate Social Environmental Reporting", Prentice Hall, London

Gul, F., \& Leung, S. (2004), "Board Leadership, Outside Directors' Expertise and Voluntary Corporate Disclosures", Journal of Accounting and Public Policy 23, 351-379.

Haniffa, R., \& Cooke, T. (2002), "Culture, Corporate Governance and Disclosure in Malaysian Corporations", ABACUS 38 (3), 317-349.

Healy, P.,\& Palepu, K. (2001), "Information asymmetry, corporate disclosure and capital markets: A review of the empirical disclosure literature", Journal of Accounting and Economics 31, 405-440.

Hossain, M. \& Hammami, H. (2009), "Voluntary disclosure in the annual reports of an emerging country: The case of Qatar", Advances in International Accounting 25, 255-265. 
Hossain, M., \& Reaz, M. (2007), "Determinants and characteristics of voluntary disclosure by Indian banking companies", Environment Management 14(5), 274-288.

Hossain, M., Perrera, M., \& Rahman, A. (1995), "Voluntary disclosure in the annual reports of New Zealand Companies", Journal of International Financial Management and Accounting 6, 69-87.

Jensen, M. \& Meckling, W. (1976), "Theory of the firm: managerial behavior, agency costs and ownership structure", Journal of Financial Economics 3, 305-360.

Kohl, N. \& Schaefers, W. (2012), "Corporate governance and market valuation of publicly traded real estate companies: evidence from Europe”, Journal of Real Estate Finance and Economics 44 (3), 362-93.

Lang, M., \& Lundholm, R. (2000), "Voluntary Disclosure and Equity Offerings: Reducing Information Asymmetry or Hyping the Stock?", Contemporary Accounting Research 17, 623-662.

Larmou, S., \& Vafeas, N. (2010), "The relation between board size and firm a performance in firms with a history of poor operating performance", Journal of Management and Governance 14, 61-85.

Leventis, S., \& Weetman, P. (2004), "Voluntary disclosures in an emerging capital market: Some evidence from the Athens Stock Exchange" Advances in International Accounting 17, 227-25.

Malone, D., Fries, C., \& Jones, T., (1993), “An Empirical Investigation of the Extent of Corporate Financial Disclosure in the Oil and Gas Industry", Journal of Accounting and Finance 8 (3), 249-273.

Marston, C., \& Polei, A. (2004), "Corporate reporting on the Internet by German companies", International Journal of Accounting Information Systems 5 (3), 285 - 311.

Meek, G., Roberts, C., \& Gray, S. (1995), "Factors influencing voluntary annual report disclosures by US and UK and continental European multinational corporations", Journal of international Business Studies 26, 555-572.

Millar, C., Eldomiaty, T., Choi, C., \& Hilton, B. (2005), "Corporate governance and institutional transparency in emerging markets", Journal of Business Ethics 59 (1-2), 163-74.

Mitton, T. (2002), "A cross-firm analysis of the impact of corporate governance on the East Asian financial crisis", Journal of Financial Economics 64 (2), 215-41.

Neter, J., Wasserman, W., \& Kutner, M. H. (1989), Applied linear regression models, 2nd edition Homewood, III: Richard D. Irwin.

Owusu-Ansah, S. \& Yeoh, J. (2005), “The effect of legislation on corporate disclosure practices”, Abacus 41(1), 92-109.

Patton. J. \& Zelenka, I. (1997), "An Empirical Analysis of The Determinants of The Extent of Disclosure in Annual Reports of Joint Stock Companies In The Czech Republic", European Accounting Review 6(4): 605-626.

Petersen, C., \& Plenborg, T. (2006), "Voluntary Disclosure and Information Asymmetry in Denmark", Journal of International Accounting, Auditing and Taxation 15: 127-149.

Raffournier, B. (1995), "The determinants of voluntary financial disclosure by Swiss listed companies", The European Accounting Review 4, 261-280.

Rees, W., \& Weisbach, M. (2002), "Protection of minority shareholder interests, cross-listing in the United States, and subsequent equity offerings", Journal of Financial Economics 66(1), 65-104.

Salter, S.B. (1998), "Corporate financial disclosure in emerging markets: does economic development matter?", The International Journal of Accounting 33 (2),211-34.

Samaha, K. \& Dahawy, K. (2011), “An Empirical Analysis of Corporate Governance Structures and Voluntary Corporate Disclosure in Volatile Capital Markets: the Egyptian Experience", International Journal of Accounting, Auditing and Performance Evaluation (IJAAPE) 7 (1/2), 61-93.

Tower, G., Vu, K.A. \& Scully, G. (2011), "Corporate communication for Vietnamese listed firms", Asian Review of Accounting 19 (2),125-46.

Wallace, R., \& Naser, K. (1995), "Firm specific determinants of the comprehensiveness of mandatory disclosure in the corporate annual reports of firms listed on the stock exchange of Hong Kong", Journal of Accounting and Public Policy 14, 311-368.

Wallace, R., Naser, K., \& Mora, A. (1994), "The Relationship between the Comprehensiveness of Corporate Annual Reports and Firm Characteristics in Spain”, Accounting and Business Research, 5 (97), 41-53.

Wang, K., Sewon, O., \& Claiborne, C. (2008), "Determinants and consequences of voluntary disclosure in an emerging market: Evidence from China", Journal of International Accounting, Auditing and Taxation $17,14-30$.

Watts, R., \& Zimmerman, J. (1990), "Positive accounting theory: a ten year perspective", The Accounting Review 65, 131-157.

Weisberg, S. (1985). Applied Linear Regression, 2nd edn. Wiley: New York.

Young, D. \& Guenther, D. (2003), "Financial reporting environments and international capital mobility", Journal of Accounting Research 41 (3), 553-79. 
Appendix A: List of Voluntary Disclosure Items.

\begin{tabular}{|c|c|}
\hline Category & Voluntary disclosure items \\
\hline $\begin{array}{l}\text { Strategy } \\
15 \text { items }\end{array}$ & $\begin{array}{l}\text { General presentation of the company's strategy } \\
\text { Main corporate goals or objectives } \\
\text { Main actions taken to achieve the corporate goals } \\
\text { Definition of the deadline for each corporate goal } \\
\text { Corporate position related to ethic/social questions } \\
\text { Corporate position related to environment issues } \\
\text { Detailed segment/unit performance } \\
\text { Evaluation of the commercial risk } \\
\text { Evaluation of the financial risk } \\
\text { Evaluation of other risks } \\
\text { Corporate I\&D/Innovation policy } \\
\text { Organizational Culture } \\
\text { Main events of the current year } \\
\text { Information about annalists } \\
\text { Other important strategic information }\end{array}$ \\
\hline $\begin{array}{l}\text { Market and Competition } \\
11 \text { items }\end{array}$ & $\begin{array}{l}\text { Identification of the principal markets } \\
\text { Specific characteristics of these markets } \\
\text { Dimension of the markets } \\
\text { Identification of the main competitors } \\
\text { Market shares } \\
\text { Forecast of market growth } \\
\text { Forecast of share market growth } \\
\text { Impact of competition on profits } \\
\text { Identification of markets' barriers to entry } \\
\text { Impact of markets barriers to entry on future profits } \\
\text { Impact of competition on future profits }\end{array}$ \\
\hline $\begin{array}{l}\text { Management and Production } \\
11 \text { items }\end{array}$ & $\begin{array}{l}\text { Identification of the principal products/services } \\
\text { Specific characteristics of these products/services } \\
\text { Proposal for new products/services } \\
\text { Changes in production/services methods } \\
\text { Investment in production/services } \\
\text { Norms of the quality of the product/service } \\
\text { Rejection/defect rates (when applicable) } \\
\text { Input/output rates (when applicable) } \\
\text { Volume of materials consumed (when applicable) } \\
\text { Change in product materials (when applicable) } \\
\text { Life cycle of the product (when applicable ) }\end{array}$ \\
\hline $\begin{array}{l}\text { Future perspective } \\
8 \text { items }\end{array}$ & $\begin{array}{l}\text { Result application proposal } \\
\text { New action/initiative/event } \\
\text { Forecasts of sales/results/cash flows } \\
\text { Investment forecasts } \\
\text { Return rates for each investment project } \\
\text { Hypothesis considered in forecast } \\
\text { Dividend policy } \\
\text { Macroeconomic background }\end{array}$ \\
\hline $\begin{array}{l}\text { Marketing } \\
7 \text { items }\end{array}$ & $\begin{array}{l}\text { Disclosure of marketing strategy } \\
\text { Disclosure of sales strategy } \\
\text { Disclosure of distribution channels } \\
\text { Disclosure of sales and marketing costs } \\
\text { Disclosure of brand equity/visibility ratings } \\
\text { Disclosure of the costumer satisfaction level } \\
\text { Disclosure of customer mix }\end{array}$ \\
\hline $\begin{array}{l}\text { Human capital } \\
8 \text { items }\end{array}$ & $\begin{array}{l}\text { Description of workforce } \\
\text { Description of the remuneration/ compensation system } \\
\text { Qualification policy of workers } \\
\text { Value created by worker } \\
\text { Employee retention rates } \\
\text { Productivity indicators } \\
\text { Strategies to measure human capital } \\
\text { Other measures of Human capital }\end{array}$ \\
\hline
\end{tabular}


This academic article was published by The International Institute for Science, Technology and Education (IISTE). The IISTE is a pioneer in the Open Access Publishing service based in the U.S. and Europe. The aim of the institute is Accelerating Global Knowledge Sharing.

More information about the publisher can be found in the IISTE's homepage: http://www.iiste.org

\section{CALL FOR JOURNAL PAPERS}

The IISTE is currently hosting more than 30 peer-reviewed academic journals and collaborating with academic institutions around the world. There's no deadline for submission. Prospective authors of IISTE journals can find the submission instruction on the following page: http://www.iiste.org/journals/ The IISTE editorial team promises to the review and publish all the qualified submissions in a fast manner. All the journals articles are available online to the readers all over the world without financial, legal, or technical barriers other than those inseparable from gaining access to the internet itself. Printed version of the journals is also available upon request of readers and authors.

\section{MORE RESOURCES}

Book publication information: http://www.iiste.org/book/

Recent conferences: http://www.iiste.org/conference/

\section{IISTE Knowledge Sharing Partners}

EBSCO, Index Copernicus, Ulrich's Periodicals Directory, JournalTOCS, PKP Open Archives Harvester, Bielefeld Academic Search Engine, Elektronische Zeitschriftenbibliothek EZB, Open J-Gate, OCLC WorldCat, Universe Digtial Library, NewJour, Google Scholar

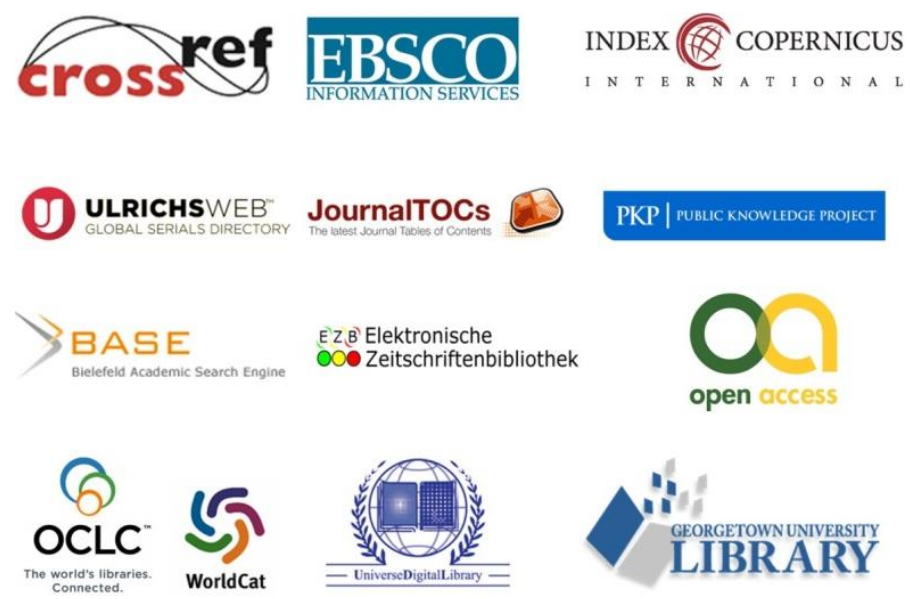

